\title{
The synergistic hepatoprotective potential of Beta vulgaris juice and 2,3- dimercaptosuccinic acid in lead-intoxicated rats via improving the hepatic oxidative and inflammatory stress
}

Nadia Z. Shaban ${ }^{1}$, Samah A. Abdelrahman ${ }^{1}$, Mohamed A. L. El-Kersh', Fayed A. K. Mogahed ${ }^{2}$, Iman M. Talaat ${ }^{3}$ and Noha H. Habashy ${ }^{{ }^{*} \text { (D) }}$

\begin{abstract}
Background: Lead $(\mathrm{Pb})$ is observed in all areas of the environment, mainly derived from human operations such as mining, processing, and burning fossil fuels. Pb toxicity is one of the most prevalent causes of human hepatotoxicity. The available chelator drugs used now have many adverse effects and therefore the world is looking for natural and secure alternatives.

Methods: Here, we evaluated the hepatoprotective role of the oral administration ( $1 \mathrm{~g} / \mathrm{kg}$ b.w.) of the lyophilized Beta vulgaris juice (BVJ) against $\mathrm{Pb}$-induced rat hepatotoxicity. We also examined the possible synergistic hepatoprotective impact of the combination between BVJ and 2,3- dimercaptosuccinic acid (DMSA, the currently approved drug for Pbtoxicity). The evaluation depends on the ability of BVJ, DMSA, or their combination (BVJ-DMSA) to reduce serum and hepatic $\mathrm{Pb}$ level and to avoid oxidative stress and inflammation caused by $\mathrm{Pb}$. The level of lipid peroxidation, reduced glutathione (GSH), total antioxidant capacity, and the activity of the antioxidant enzymes were quantified. In addition, the level of interleukin (IL)-6, nitric oxide (NO), DNA fragmentation, and liver histology were studied.

Results: The results showed that BVJ contained considerable amounts of betalains, vitamin C, and various types of phenolic compounds. Therefore, BVJ displayed a significant $(p<0.05)$ preventive influence on the elevation of Pb levels in blood and liver as well as the hepatic DNA fragmentation. In addition, it significantly $(p<0.05)$ improved most of the studied antioxidant and inflammatory markers in the Pb-intoxicated rats. However, the combined extract (BVJ-DMSA) revealed synergistic (combination index $<1$ ) activities in most of the tested parameters. The histopathological results verified the biochemical findings of this research.

(Continued on next page)
\end{abstract}

\footnotetext{
* Correspondence: noha.Habashi@alexu.edu.eg; nohahhm@gmail.com 'Biochemistry Department, Faculty of Science, Alexandria University, Alexandria 21511, Egypt

Full list of author information is available at the end of the article
}

C C The Author(s). 2020 Open Access This article is licensed under a Creative Commons Attribution 4.0 International License, which permits use, sharing, adaptation, distribution and reproduction in any medium or format, as long as you give appropriate credit to the original author(s) and the source, provide a link to the Creative Commons licence, and indicate if changes were made. The images or other third party material in this article are included in the article's Creative Commons licence, unless indicated otherwise in a credit line to the material. If material is not included in the article's Creative Commons licence and your intended use is not permitted by statutory regulation or exceeds the permitted use, you will need to obtain permission directly from the copyright holder. To view a copy of this licence, visit http://creativecommons.org/licenses/by/4.0/ The Creative Commons Public Domain Dedication waiver (http://creativecommons.org/publicdomain/zero/1.0/) applies to the data made available in this article, unless otherwise stated in a credit line to the data. 


\begin{abstract}
(Continued from previous page)
Conclusion: BVJ has a potent efficiency in the protection from Pb-induced hepatotoxicity through the reduction of its accumulation in blood and liver and the prevention of the oxidative stress and inflammation induced by $\mathrm{Pb}$.

Additionally, the treatment of hepatotoxicity with BVJ and DMSA in combination showed a synergistic effect and reduced the adverse effects induced by DMSA. Thus, BVJ can be a promising hepatoprotective extract against lead toxicity and its combination with DMSA potentiates this effect.
\end{abstract}

Keywords: Beta vulgaris juice, 2,3- dimercaptosuccinic acid, Lead hepatotoxicity, Oxidative stress, Inflammation, Synergism

\section{Background}

The liver is the largest internal organ and gland of the human body. It has a weight of $1.4-1.6 \mathrm{~kg}$ in the adult, which represents about $2 \%$ of the whole-body weight. It has several functions in the body such as metabolism of lipids, carbohydrates, and proteins, production of coagulation factor and albumin, as well as storage of vitamins and glycogen. In addition, it detoxifies xenobiotics and drugs, so it can expose to several diseases including toxicity [1]. Hepatotoxicity can also be induced by natural chemical agents (such as aflatoxin), industrial agents, and heavy metals (such as lead, $\mathrm{Pb}$ ) [2]. The $\mathrm{Pb}$ is a toxic heavy metal with a wide abundance in the earthand it can be absorbed via the respiratory system, gastrointestinal tracts, and rarely through the skin [3]. After absorption, $\mathrm{Pb}$ is distributed in the blood, bone, and soft tissues, while the liver is the main storehouse (33\%). It can interact with the cellular macromolecules causing proteins dysfunction, lipid peroxidation, DNA damage, and oxidative stress (OS) [2]. OS is an imbalance between free radicals [reactive oxygen (ROS) and nitrogen (RNS) species] and antioxidants [4]. OS induces hepatocyte inflammation, proliferation, necrosis, loss of hepatic reticular fiber, fatty changes, and mild fibrosis [5].

Chelation therapy is a conventional way to treat heavy metal poisoning [6] by creating an insoluble, less toxic metal-complex [7] that can easily be excreted from the body [6]. 2,3-dimercaptosuccinic acid (DMSA, succimer) is the ideal chelating agent for $\mathrm{Pb}$ in children and sensitive adults [8]. However, it has several adverse effects, including increased levels of alanine aminotransferase (ALT) and aspartate aminotransferase (AST) [6] and is unable to remove $\mathrm{Pb}$ from hard tissues such as bones. Therefore, the use of DMSA in chronic cases of $\mathrm{Pb}$ injury is limited [9].

Nowadays, huge kinds of vegetables, herbs, and medicinal plants are suggested for the treatment of hepatotoxicity [10]. For the first time, the current study evaluated the protective role of Beetroot (Beta vulgaris, $\mathrm{BV})$ juice (BVJ) against $\mathrm{Pb}$-induced $\mathrm{OS}$ and injury to the rat liver. In addition, we studied the possible hepatoprotective synergism of the combination between BVJ and DMSA. The BV is the taproot part of the beet plant belonging to the Chenopodiaceae family and considered to be vegetable and fruit. It is distributed all over the world and has been cultured for hundreds of years in all temperate climates. The BV is an important source of nitrogenous pigments called betalains (yellow betaxanthins and red betacyanins). In addition, it contains many functional constituents such as polyphenols, vitamins, minerals, and others. Therefore, BV is considered as a medicinal plant with hepatoprotective and antioxidant effects and can be used in the treatment of several diseases [11]. In the present study, the functional constituents and antioxidant properties of BVJ were examined to explain its expected hepatoprotective action against $\mathrm{Pb}$ intoxication in rats.

\section{Methods \\ Chemicals}

Folin-ciocalteau reagent, 4-hydroxycinnamic acid (4HCA), rutin (RU), catechin, butylated hydroxytoluene (BHT), 2,2- azino-bis(3-ethylbenzthiazoline-6-sulfonic acid (ABTS),monoisoamylDMSA, thiobarbituric acid (TBA), reduced glutathione (GSH), and 5,5'-\{dithiobis2-nitrobenzoic acid\} (DTNB) were obtained from SigmaAldrich (St. Louis, MO, USA). Lead acetate was purchased from ISO-CHEM, France. Alkaline phosphatase (ALP), Albumin, ALT and AST kits were obtained from Giesse Diagnostics, Italy. Urea and creatinine kits were supplied by Diamond Diagnostics, Egypt. Easy-spin ${ }^{\text {tm }}$ [DNA free] total RNA extraction kit was obtained from iNtRON Biotechnology, South Korea. SensifastsyBr loRox one-step kit and MyTaq Red Mix kit were purchased from Bioline (USA). Primers and 50 bP DNA ladder kit were obtained from Vivantis (USA) and Genedirx (USA), respectively. Rat IL-6 ELISA kit was purchased from RayBiotech (Norcross, USA). Other chemicals were obtained with a high grade.

\section{BVJ preparation}

The BV plant (NCBI:txid3555) was purchased from specific herbal stores in Alexandria, Egypt. After authentication and identification of the plant by the experts in these stores, it was pressed using a dry household juice extractor to get the juice, which was lyophilized (Telstar, 
Terrassa, Spain). The powdered form (yield $13 \mathrm{~g} / 100 \mathrm{~mL}$ juice) has been stored at $-20^{\circ} \mathrm{C}$ until used.

\section{BVJ constituents}

Some constituents in BVJ, including total phenolics, flavonoids, tannins, betalains, anthocyanins as well as vitamin $C$, were quantified. Total phenolic compounds in mg 4-HCA equivalents/g extract were estimated colorimetrically at $750 \mathrm{~nm}$ after reduction of Folin-Ciocalteau reagent by juice phenolics [12]. Total flavonoids were measured at $510 \mathrm{~nm}$ after mixing an aliquot of BVJ with $\mathrm{NaNO}_{2}(5 \%)$ and $\mathrm{AlCl}_{3}(10 \%)$ and the concentration in mg RU equivalents/g extract was calculated using RU standard curve [13]. While the tannin content of the extract was quantified by the modified vanillin assay using the catechin calibration curve [14]. Total betalains (betacyanins and betaxanthins) were quantified by measuring the diluted solution of BVJ at three different wave lengths, $536 \mathrm{~nm}, 485 \mathrm{~nm}$, and $650 \mathrm{~nm}$ (impurities) [15]. The concentration of betacyanins or betaxanthins has been calculated using the following equation:

$$
\left[\text { Betacyanins or betaxanthins }(\mathrm{mg} / \mathrm{L})=\frac{A x M . W x D F x 1000}{e x i}\right] .
$$

Where, $\mathrm{A}=\mathrm{A}_{\mathbf{5 3 6}}-\mathrm{A}_{\mathbf{6 5 0}}$ (for betacyanins) or $\mathrm{A}_{\mathbf{4 8 5}}$ $\mathrm{A}_{650}$ (for betaxanthins), M.W: molecular weight of betacyanins or betaxanthins (550 or $336 \mathrm{~g} / \mathrm{mol}$, respectively), DF: Dilution factor, $\epsilon$ : molar extinction coefficient for betacyanins or betaxanthins $(60,000$ or $48,000 \mathrm{~L} / \mathrm{molcm}$, respectively), i: path length $(\mathrm{cm})$. Anthocyanins were quantified by a $\mathrm{pH}$-differential assay that based on the reversible structural transformation of these pigments due to $\mathrm{pH}$ change [16]. The sample was mixed with two buffer solutions $(\mathrm{pH} 1.0$ and $\mathrm{pH} 4.5)$ and the absorbance has been measured at 510 and $700 \mathrm{~nm}$ for each $\mathrm{pH}$. The absorbance of the sample $\left(\mathrm{A}_{\mathrm{s}}\right)$ was calculated from the equation: $\left[\mathbf{A s}=\left(\mathbf{A}_{510}-\mathbf{A}_{\mathbf{7 0 0}}\right)_{\mathbf{p H ~ 1 . 0}}-\left(\mathbf{A}_{\mathbf{5 1 0}}-\mathbf{A}_{\mathbf{7 0 0}}\right)_{\mathbf{p H}}\right.$ 4.5] Whereas the anthocyanins concentration was determined as cyanidin-3-glucoside (Cy-3-glc) equivalent using the equation:

$$
\left[\text { anthocyanin pigment }=\frac{\left(\mathrm{A}_{\mathbf{s}} \times \mathrm{MW} \times \mathrm{DF} \times 1000\right)}{(\varepsilon \times \text { sample weight })}\right] .
$$

Where MW is the molecular weight of Cy-3-glc and $\varepsilon$ is its molar absorptivity, DF is the sample dilution factor.

Vitamin $\mathrm{C}$ concentration has been measured spectrophotometrically by 2,4 dinitrophenyl hydrazine $(2,4$ DNPH) and the standard vitamin [17]. The deproteinized extract or standard was incubated for $1.5 \mathrm{~h}$ with a solution of 2,4-DNPH (3\%), $\mathrm{CuSO}_{4}(0.05 \%)$, thiourea (0.4\%), and $\mathrm{H}_{2} \mathrm{SO}_{4}(9 \mathrm{~N})$ at $37^{\circ} \mathrm{C}$. At the end of the incubation period, $\mathrm{H}_{2} \mathrm{SO}_{4}$ was added and the absorbance of the colored product was recorded at $520 \mathrm{~nm}$ after $30 \mathrm{~min}$.

\section{HPLC analysis for identification and quantification of phenolics}

Using specific phenolic standards, the BVJ phenolics were identified and quantified at $284 \mathrm{~nm}$ using Agilent 1260 Infinity HPLC series (Agilent Technologies, Palo Alto, CA, USA) [18]. The BVJ $(20 \mu \mathrm{L})$ was separated by a ternary linear elution gradient on a $100 \mathrm{~mm} \times 4.6 \mathrm{~mm}$ Kinetex EVO C18 column and eluted using $0.2 \% \mathrm{H}_{3} \mathrm{PO}_{4}$, methanol, and acetonitrile.

\section{Evaluation of the antioxidant properties of BVJ}

The antioxidant properties of BVJ, DMSA, and BVJDMSA (160:1) were evaluated in vitro using different methods, including total antioxidant capacity (TAC), $\mathrm{ABTS}^{+}$radical cation decolorization, $\beta$-carotenelinoleate bleaching, and ferric reducing power. In all of these assays, except the TAC, different concentrations $(0.25-0.01 \mathrm{mg} / \mathrm{mL})$ of the samples were used.

The TAC has been determined at $695 \mathrm{~nm}$ using a mixture of $28 \mathrm{mM}$ sodium phosphate, $4 \mathrm{mM}$ ammonium molybdate, and $0.6 \mathrm{M} \mathrm{H}_{2} \mathrm{SO}_{4}$ [19]. The results were expressed as BHT equivalents in $\mathrm{mg} / \mathrm{g}$ of juice using the BHT calibration curve. The $\mathrm{ABTS}^{+}$radical cationdecolorization ability was assessed by reducing and decolorizing the blue-green chromophore $\mathrm{ABTS}^{+}$by the studied samples to ABTS [20]. The absorbance of the extract or control (no reduction) was read at $734 \mathrm{~nm}$ and the percentage of $\mathrm{ABTS}^{+}$inhibition was calculated using the following equation:

$$
\begin{aligned}
\text { Radical inhibition }(\%)= & \left(\mathrm{A}_{\text {Control }}-\mathrm{A}_{\text {Sample }} / \mathrm{A}_{\text {Control }}\right) \\
& \times 100 .
\end{aligned}
$$

The $\beta$-carotene bleaching assay was determined to evaluate the anti-lipid peroxidation activity of the studied samples (BVJ, DMSA, or BVJ-DMSA) [21]. The ability of samples to prevent $\beta$-carotene bleaching in the emulsion of $\beta$-carotene, linoleic acid, and Tween- 80 was detected at $490 \mathrm{~nm}$. The absorbance $(a, b)$ was recorded instantly and after $180 \mathrm{~min}(t)$, respectively then the degradation rate (DR) of the sample, control (water), and standard $(\mathrm{BHT})$, was calculated using the equation: $[\mathrm{DR}=\ln (a / b) \times(1 / t)]$. Then the antioxidant ability was calculated as \% of inhibition using the equation: antioxidant activity $(\%)=\left(\mathrm{DR}_{\text {Control }}-\mathrm{DR}_{\text {Sample }} / \mathrm{DR}_{\text {Control }}\right) \times$ 100 to calculate the $\mathrm{IC}_{50}$ values (a concentration that inhibits the $\beta$-carotene bleaching by $50 \%$ ). Ferric reducing power has been assessed using the potassium ferricyanide-ferric chloride method [22]. In this assay, each of the DMSA, single or combined extract or Asc was incubated with phosphate buffer ( $\mathrm{pH} 6.6,0.2 \mathrm{M})$ and potassium ferricyanide $(1 \%)$ at $50^{\circ} \mathrm{C}$ for $20 \mathrm{~min}$. The mixture was acidified with $10 \%$ trichloroacetic acid (TCA) and mixed with $1 \%$ ferric chloride to produce a 
blue color solution with a maximum absorbance at 700 $\mathrm{nm}$. Then the $\mathrm{IC}_{50}$ value (the concentration of the sample or Asc that gives 0.5 of absorbance) was calculated.

\section{Animals and experimental protocol}

Seventy-two male albino rats weighing $70 \pm 5 \mathrm{~g}$ obtained from Theodor Bilharz Research Institute, Giza, Egypt. The animals were housed in stainless cages under standard laboratory conditions of $12 \mathrm{~h}$ light/dark cycle, $55 \pm$ $5 \%$ air humidity, and $30^{\circ} \mathrm{C}$ and received a standard laboratory diet and tap drinking water for 2 weeks, as an adaptation period. All animal methodology was accomplished following the Institutional Animal Care and Use Committee (IACUC) and approved via the Committee of Animal Care and Use in Alexandria University (ethical approval reference number: AU-04200516301).

The animals have been randomly divided into 6 groups (twelve rats in each) as elucidated in (Fig. 2 I). The hepatotoxicity was induced in rats by ip injection of $\mathrm{Pb}(40 \mathrm{mg} / \mathrm{kg}$ b.w.) for 8 days,as elucidated before with modification [23]. Rats were orally administered with BVJ (1 g/kg b.w.) before, during, and after $\mathrm{Pb}$ injection, while DMSA $(50 \mathrm{mg} / \mathrm{kg}$ b.w.) was orally intaken after $\mathrm{Pb}$ administration. The treatment protocol and the studied groups were designed as described in Fig. 2 I. After termination of the experimental period (31 days), rats were sacrificed under carbon dioxide euthanasia in compliance with the euthanasia recommendations in the Guide for the Care and Use of Laboratory Animals. Blood was obtained by cardiac puncture and one portion was collected in a heparinized tube for determination of the blood $\mathrm{Pb}$ level while the other portion was allowed to clot for $30 \mathrm{~min}$ to separate serum samples. Liver tissues were excised immediately, washed with cold saline, and small pieces were fixed in 10\% formalin for histopathological examination. The remaining liver tissue was divided into two portions and kept at $-80^{\circ} \mathrm{C}$ for the molecular and biochemical analyses.

\section{Blood analysis}

The $\mathrm{Pb}$ concentration in the $\mathrm{HNO}_{3} / \mathrm{H}_{2} \mathrm{O}_{2}$ digested blood and liver samples has been quantified by atomic absorption spectrometry (Varian, model spectr AA 240, Mulgrave, Australia) [24]. In addition, the liver function parameters (albumin, ALP, ALT, and AST) and kidney function parameters (urea and Creatinine) were assessed in serum using the specific kits following the manual protocol.

\section{Determination of lipid peroxidation and antioxidant indices}

The level of lipid peroxidation, GSH, total antioxidant efficiency, and activity of superoxide dismutase (SOD), glutathione peroxidase (GPX), catalase, and glutathione S-transferase (GST) $\alpha-1$ were determined in the liver homogenate. The liver was homogenized in a phosphate buffer ( $\mathrm{pH} 7)$ and a clear supernatant was obtained for the analyses after centrifugation at $6000 \mathrm{rpm}$ for $15 \mathrm{~min}$. The lipid peroxidation level was determined by quantification of the TBA reactive substances (TBARS) level [25]. The GSH content was assessed by the reduction and cleavage of DTNB via GSH sulfhydryl group yielding a yellow-colored product with a maximum absorbance at $412 \mathrm{~nm}$ [26]. The total antioxidant efficiency of the liver tissue homogenates was assessed by the $\mathrm{ABTS}^{+}$radical cation-decolorization method [20]. The method determines the degree of the disappearance of the blue-green color at $734 \mathrm{~nm}$ upon the reduction of the $\mathrm{ABTS}^{+}$radical to ABTS by the homogenate antioxidants. For the preparation of the $\mathrm{ABTS}^{+}$radical, 7 $\mathrm{mM}$ ABTS was incubated with $140 \mathrm{mM}$ potassium persulphate at $25 \mathrm{C}$ for $16 \mathrm{~h}$ in the dark. The total antioxidant activity which expressed as $\mu \mathrm{mol}$ BHT equivalent/g liver was calculated using the BHT calibration curve.

The activity of $\mathrm{Cu} / \mathrm{Zn}$ SOD was determined by quantifying the ability to inhibit the pyrogallol $(20 \mathrm{mM})$ autoxidation at $420 \mathrm{~nm}$ [27]. One unit of activity is defined as the amount of the enzyme that inhibits the autooxidation reaction by $50 \%$. The GPx activity was assessed colorimetrically using GSH and cummen hydrogen peroxide as substrates [28]. Catalase activity was determined spectrophotometrically by recording the cleavage of hydrogen peroxide at $240 \mathrm{~nm}$ [29]. The activity of GST was determined colorimetrically using pnitrobenzyl chloride as a substrate [30]. In addition, the gene expression of GST $\alpha-1$ was determined by reverse transcription-quantitative polymerase chain reaction (RT-qPCR, BIO-RAD Laboratories, Inc., USA). Therefore, the total RNA was isolated from $100 \mathrm{mg}$ of liver tissue by the RNA extraction kit, following the instruction protocol, then the purity and concentrations of the RNA samples were assessed by Nano-spectrometry (BioDrop $\mu$ LITE, Cambridge, UK). The cDNA of the internal control (glyceraldehyde-3-phosphate dehydrogenase, GAPD $\mathrm{H})$ and target genes were synthesized and amplified in a one-step reaction using specific forward and reverse primers as follow: GST $\alpha 1$ (forward); $5^{\prime}-G C A T C A$ GCT TGC CCT TCA-3', GST $\alpha 1$ and (reverse); 5'-AAA CGC TGT CAC CGT CCT -3', GAPDH (forward); 5'-AGC CCA GAA CAT CAT CCC TG-3', GAPDH (reverse); 5'CAC CAC CTT CTT GAT GTC ATC-3'. The relative expression was measured by the RT-qPCR cycling program of one reverse transcription cycle $\left(45^{\circ} \mathrm{C}\right.$ for 10 min) followed by polymerase activation $\left(95^{\circ} \mathrm{C}\right.$ for 2 min). Then the denaturation $\left(95^{\circ} \mathrm{C}\right.$ for $\left.5 \mathrm{~s}\right)$, annealing $\left(60^{\circ} \mathrm{C}\right.$ for $\left.10 \mathrm{~s}\right)$, and extension $\left(72^{\circ} \mathrm{C}\right.$ for $\left.5 \mathrm{~s}\right)$. The expression of GST $\alpha-1$ gene was calculated by the comparative Ct method (threshold cycle number at crosspoint between amplification plot and threshold). The CT value was normalized to that of GAPDH according to the manufacturer's protocol and the change in the gene expression was calculated using the $2^{-\Delta \Delta C T}$ equation. 


\section{Assessment of total protein content}

The total protein level in liver homogenate and serum was determined using the Lowery method at $650 \mathrm{~nm}$ [31]. The values of the protein level in liver homogenate have been used to calculate the specific activity of the antioxidant enzymes as unit activity/mg of protein.

\section{Determination of the inflammatory biomarkers}

The level of both interleukin-6 (IL-6) and nitric oxide (NO) were assessed in the liver tissue of all the studied groups. The protein level of IL-6 was determined using a specific ELISA kit following the instruction protocol. Griess reagent (0.1\% naphthyl ethylenediamine dihydrochloride, $1 \%$ sulfanilamide, and $2 \%$ phosphoric acid) used to quantify the NO level colorimetricallyat $490 \mathrm{~nm}$ [32].

\section{Assessment of hepatic DNA fragmentation}

The degree of DNA fragmentation was assessed spectrophotometrically as shown previously with some modifications [33]. In brief, $25 \mathrm{mg}$ of liver tissue was homogenized in phosphate buffer " $\mathrm{pH} 7.0$ " then $250 \mu \mathrm{l}$ of DNA lysis buffer "TTE” ( $1 \mathrm{M}$ Tris-HCI pH 8, $0.2 \%$ Triton X-100, and 0.5 M EDTA) was added. Lysed cells were centrifuged for $10 \mathrm{~min}$ at $15000 \mathrm{rpm}\left(4^{\circ} \mathrm{C}\right)$. Then $0.5 \mathrm{~mL}$ of TTE solution was mixed with pellet and $50 \mu \mathrm{l}$ of ice-cold $\mathrm{NaCl}(5 \mathrm{M})$ was vigorously mixed with supernatant prior to DNA precipitation with isopropanol. The DNA was washed via70\% ethanol, dissolved in deionized water-RNase solution, and then incubated at $37^{\circ} \mathrm{C}$ for 2 days. The absorbance (OD) was read at $260 \mathrm{~nm}$ using a nanodrop spectrophotometer then DNA fragmentation (\%) was determined according to the equation: $\left[\left(\mathrm{OD}_{\text {supernatant }} / \mathrm{OD}_{\text {supernatant }}+\mathrm{OD}_{\text {pellet }}\right)\right] \times 100$

\section{Drug combination index $(\mathrm{Cl})$ analysis}

The drug and food combination may offer greater (synergistic), lesser (antagonistic), or no new (additive) outcome compared to the single agent. This new result can be investigated by calculating the CI value (the predictable value divided by the observed value). The predictable value for BVJ-DMSA was calculated by the summation of the BVJ and DMSA half values for each studied in vitro antioxidant assay. While for other tested parameters, the predictable value is determined as [(observed value for $\mathrm{BVJ}) /($ control value)] X [(observed value for DMSA)/ (control value)] X (control value) [34]. From the obtained value, the effect can be evaluated as synergism $(\mathrm{CI}<1)$, antagonism $(\mathrm{CI}>1)$, or additive $(\mathrm{CI}=1)$ $[35,36]$.

\section{Histopathological study}

The histopathology was done using the routine protocol. After fixation of the liver specimens, they have been embedded in paraffin wax and cut into thin slices with a thickness of $5 \mu \mathrm{m}$ with a microtome then stained with hematoxylin and eosin for examination [37].

\section{Statistics}

All data are expressed as mean \pm standard error (SE). The statistical analysis was performed by SPSS (Statistical Package for Social Sciences) software version 25.0 usingone-way analysis of variance (ANOVA). The post hoc analysis using Dunnett's test was followed and the values of $p<0.05$ were considered as statistically significant. Heat map plots were obtained by ClustVis web server (https://biit.cs.ut.ee/clustvis/) [38].

\section{Results \\ BVJ constituents}

Table 1 represents the constituents of BVJ, which included significant quantities of phenolics (flavonoids, Anthocyanins, Tannins), betalains and vitamin C. The HPLC analysis identified twelve phenolic compounds in BVJ (Fig. 1 I, Table 1) using known phenolic standards by comparing their particular retention times.

Table 1 Composition of some constituents in Beta vulgaris juice (BVJ)

\begin{tabular}{|c|c|}
\hline Content & Constituents \\
\hline $1823.000 \pm 87.000$ & Phenolics ( $\mu \mathrm{g}$ 4-HCA Eq/ g BVJ) \\
\hline $14,187.000 \pm 216.000$ & Flavonoids ( $\mu \mathrm{g}$ RU Eq/ g BVJ) \\
\hline $88.394 \pm 0.063$ & Anthocyanins ( $\mu \mathrm{g}$ Cy-3-glc Eq./g BVJ) \\
\hline $96.526 \pm 9.717$ & Tannins ( $\mu \mathrm{g}$ catechin Eq/ g BVJ) \\
\hline $5730.000 \pm 40.000$ & Total betalains ( $\mu \mathrm{g} / \mathrm{g}$ BVJ) \\
\hline $3680.000 \pm 70.000$ & Betacyanins ( $\mu \mathrm{g} / \mathrm{g}$ BVJ) \\
\hline $2040.000 \pm 50.000$ & Betaxanthins ( $\mu \mathrm{g} / \mathrm{g}$ BVJ) \\
\hline $105.666 \pm 30.819$ & Vitamin C ( $\mu \mathrm{g} / \mathrm{g}$ BVJ) \\
\hline \multicolumn{2}{|c|}{ HPLC analysis of Phenolic compounds ( $\mu \mathrm{g} \mathrm{g}^{-1} \mathrm{BVJ}$ ) } \\
\hline 16.021 & Quinol \\
\hline ND & Caffeine \\
\hline 881.732 & Quercitin \\
\hline ND & Rutin \\
\hline 35.074 & Rosmarinic acid \\
\hline 132.339 & Benzoic acid \\
\hline ND & Ferulic acid \\
\hline 0.386 & Ellagic acid \\
\hline 1031.673 & Syringic acid \\
\hline 0.867 & Gallic acid \\
\hline 35.297 & Vanillic acid \\
\hline 121.048 & o- Coumaric acid \\
\hline
\end{tabular}

Results are presented as Mean $\pm \mathrm{SE}(n=3)$. HCA Hydroxyl cinnamic acid, $R U$ Rutin, $C y$-3-glc Cyanidin-3-glucoside, Eq Equivalent, ND Not detected. 


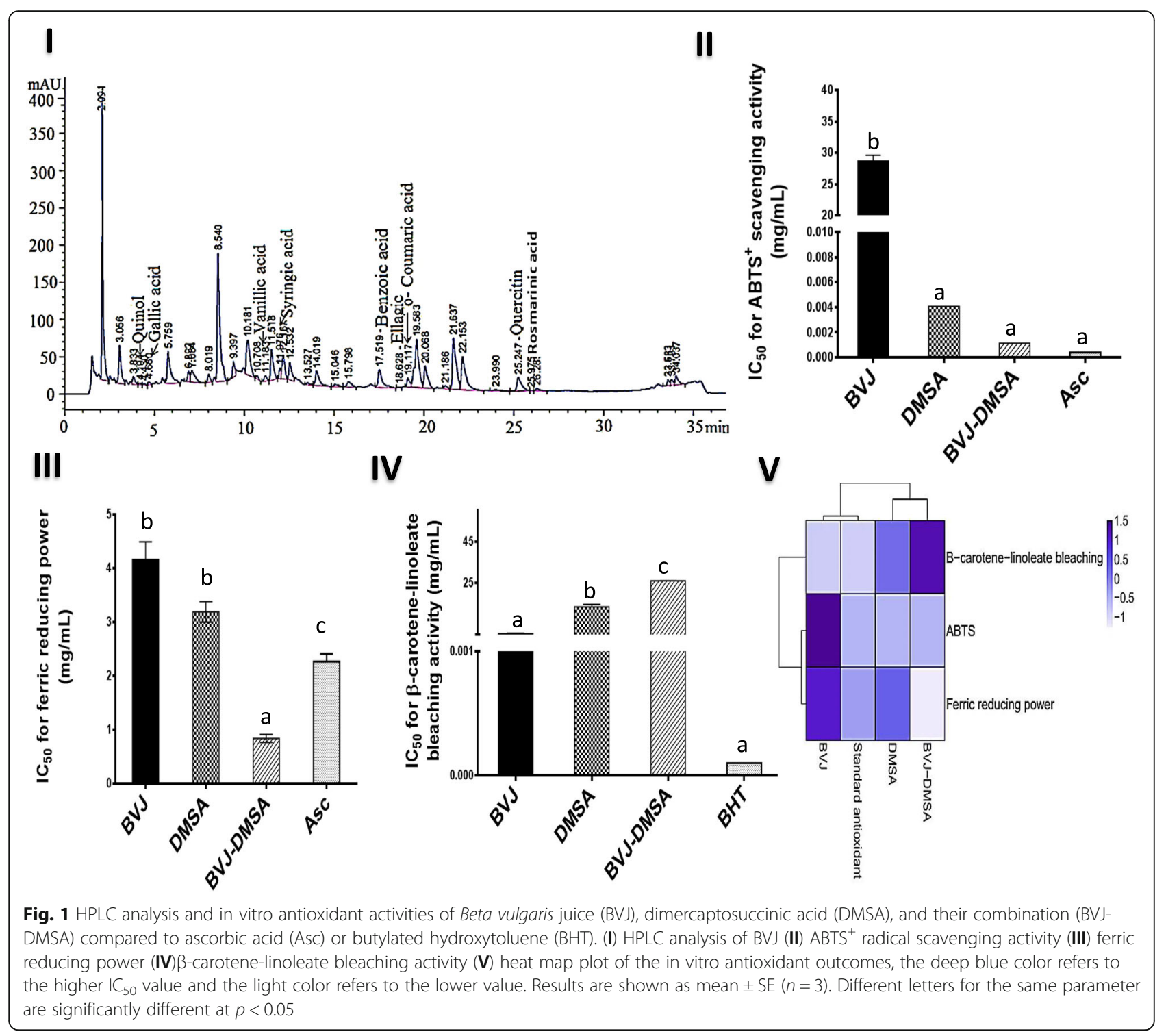

In vitro antioxidant activities of BVJ and DMSA

Graphs II-IV in Fig. 1 revealed the in vitro antioxidant activities of BVJ, DMSA, and BVJ-DMSA compared to Asc or BHT. BVJ showed higher $(p<0.05) \mathrm{IC}_{50}$ values for $\mathrm{ABTS}^{+}$radical scavenging activity than the DMSA value (Fig. 1 II). Compared to Asc, BVJ showed significant $(p<0.05)$ lower power and the comparable impact was shown by DMSA. Concerning ferric reducing power (Fig. $1 \mathrm{III}$ ), both BVJ and DMSA had the same potency that was significantly $(p<0.05)$ smaller than Asc. The $\beta$ carotene-linoleate bleaching activity of BVJ was significantly $(p<0.05)$ more than DMSA and both exhibited significant $(p<0.05)$ lower activity than BHT (Fig. 1 IV). On the other hand, the combination of BVJ and DMSA $(B V J-D M S A)$ revealed synergistic $(\mathrm{CI}<1) \mathrm{ABTS}^{+}$radical scavenging and ferric reducing power activities (Table 2) with similar or higher potency compared to Asc, respectively. However, the $\beta$-carotene-linoleate bleaching activity of BVJ-DMSA exhibited antagonistic $(\mathrm{CI}>1)$ influence and lower potency than BHT. The heat map plot (Fig. $1 \mathrm{~V}$ ) clustered these in vitro antioxidant results, where the deep blue color shows higher $\mathrm{IC}_{50}$ value (lower potency) and the light color indicates the lower value (higher potency).

Liver and kidney biomarkers levels before and after administration of BVJ, DMSA, and their combination in $\mathrm{Pb}$-intoxicated rats

As shown in (Fig. 2 II, III), Pb administration did not significantly change the serum levels of kidney biomarkers (urea and creatinine), as well as ALT activity and total protein level by about $25.43,47.17,59.77$, and $6.80 \%$, respectively, compared to the control samples. Nevertheless, the activity of AST and ALP elevated significantly $(p<0.05)$ by approximately 75.76 and $80.09 \%$, 
Table 2 The combination index $(\mathrm{Cl})^{*}$ values for the Beta vulgaris juice (BVJ) and meso-2,3-dimercaptosuccinic acid (DMSA) mixture on the tested parameters

\begin{tabular}{|c|c|c|}
\hline Parameters & $\mathrm{Cl}$ & Effect \\
\hline \multicolumn{3}{|l|}{ In vitro antioxidant models } \\
\hline ABTS $(\mathrm{mg} / \mathrm{mL})$ & $0.000 \pm 0.000$ & Synergistic \\
\hline$\beta$-carotene bleaching $(\mathrm{mg} / \mathrm{mL})$ & $3.764 \pm 0.122$ & Antagonistic \\
\hline Ferric reducing power (mg/mL) & $0.245 \pm 0.026$ & Synergistic \\
\hline \multicolumn{3}{|l|}{ Liver function parameters } \\
\hline $\operatorname{ALT}(U / L)$ & $0.866 \pm 0.072$ & Synergistic \\
\hline AST $(U / L)$ & $0.545 \pm 0.148$ & Synergistic \\
\hline ALP $(U / L)$ & $0.626 \pm 0.129$ & Synergistic \\
\hline Albumin (mg/dl) & $0.893 \pm 0.107$ & Synergistic \\
\hline Total protein (g/dl) & $1.006 \pm 0.062$ & Additive \\
\hline \multicolumn{3}{|l|}{ Kidney function markers } \\
\hline Urea (mg/dl) & $0.798 \pm 0.067$ & Synergistic \\
\hline Creatinine (mg/dl) & $0.725 \pm 0.077$ & Synergistic \\
\hline \multicolumn{3}{|l|}{ Lead concentration } \\
\hline Blood lead level ( $\mu \mathrm{g} / \mathrm{dl})$ & $0.037 \pm 0.012$ & Synergistic \\
\hline Hepatic lead Level ( $\mu \mathrm{g} / \mathrm{g}$ tissue) & $0.062 \pm 0.013$ & Synergistic \\
\hline \multicolumn{3}{|l|}{ Oxidative stress markers } \\
\hline Lipid peroxidation (pmol/g tissue) & $0.641 \pm 0.050$ & Synergistic \\
\hline GSH (mg/g tissue) & $0.864 \pm 0.019$ & Synergistic \\
\hline TAC ( $\mu \mathrm{g}$ BHT Eq/g tissue) & $0.969 \pm 0.136$ & Synergistic \\
\hline SOD (IU/mg protein) & $0.624 \pm 0.144$ & Synergistic \\
\hline GPX (IU/mg protein) & $0.655 \pm 0.099$ & Synergistic \\
\hline Catalase (IU/mg protein) & $0.7663 \pm 0.162$ & Synergistic \\
\hline GST (IU/mg protein) & $1.1262 \pm 0.226$ & Antagonistic \\
\hline GST a1 (expression fold) & $1.814 \pm 0.600$ & Antagonistic \\
\hline \multicolumn{3}{|l|}{ Inflammatory parameters } \\
\hline NO (mmol/g tissue) & $0.677 \pm 0.119$ & Synergistic \\
\hline IL-6 (pg/g tissue) & $0.402 \pm 0.100$ & Synergistic \\
\hline DNA fragmentation (\%) & $0.844 \pm 0.084$ & Synergistic \\
\hline
\end{tabular}

${ }^{*} \mathrm{Cl}$ value of $<1$ shows synergistic effect; $>1$ shows antagonistic effect; $=1$ shows additive effect. TAC Total antioxidant capacity, HCA Hydroxycinnamic acid, ABTS 2,2- azino-bis(3-ethylbenzthiazoline-6-sulfonic acid, BHT Butylated hydroxytoluene, ALT Alanine aminotransferase, AST Aspartate aminotransferase, ALP Alkaline phosphatase, GSH Reduced Glutathione, SOD Superoxide dismutase, GPX Glutathione peroxidase, GST Glutathione Stransferase, NO Nitric oxide, IL-6 Interleukin-6

respectively. In contrast, the level of albumin reduced significantly $(p<0.05)$ by about $12.76 \%$.

The treatment with BVJ, before, during, and after $\mathrm{Pb}$ administration changed the level of urea $(25.86 \%)$, creatinine $(10.26 \%)$, and total protein $(2.66 \%)$ and the activity of ALT (6.22\%) non significantly compared to $\mathrm{Pb}$ group. However, BVJ significantly $(p<0.05)$ prevented $\mathrm{Pb}$-induced elevation in AST activity (59.12\%) and depletion in albumin level (16.82\%), but it cannot avoid the elevation in ALP activity (14.29\%). On the other hand, the treatment with DMSA showed a non-significant elevation in the level of urea (8.47\%), creatinine (1.65\%), and total proteins $(16.79 \%)$ and the activity of ALT (13.24\%), AST (13.66\%), and ALP (1.79\%) relative to rats in $\mathrm{Pb}$ group. However, it significantly raised and normalized the level of albumin by $19.07 \%$.

The combination of BVJ and DMSA (BVJ-DMSA) showed a non-significant change in the level of urea (27.79\%), creatinine $(2.01 \%)$, and total proteins $(0.48 \%)$ and the activity of ALT (4.68\%) and ALP (23.95\%) as compared to $\mathrm{Pb}$ group. However, the level of albumin was significantly $(p<0.05)$ raised by $25.49 \%$ and the activity of AST was significantly decreased by $51.08 \%$ compared to the $\mathrm{Pb}$ group. The synergy testing (Table 2) revealed a synergistic $(\mathrm{CI}<1)$ effect of BVJ-DMSA for all the kidney and liver biomarkers except for total proteins it showed additive effect $(\mathrm{CI}=1)$.

The administration of BVJ alone to rats for 31 days demonstrated a non-significant change in the level of urea $(27.54 \%)$, creatinine (5.12\%), ALT (15.52\%), AST (54.34\%), ALP (11.51\%), albumin (10.77\%), and total proteins $(1.08 \%)$ as compared to control group.

\section{Depleting impact of BVJ, DMSA, and their combination to} blood and hepatic $\mathrm{Pb}$ levels in $\mathrm{Pb}$-intoxicated rats

As shown in Fig. $3 \mathrm{I}$, the blood and hepatic $\mathrm{Pb}$ levels were significantly $(p<0.05)$ elevated after $\mathrm{Pb}$ administration by 1413.86 and $1187.27 \%$, respectively, compared to the control group. Administration of BVJ, before, during, and after $\mathrm{Pb}$ administration significantly prevented the elevation in blood and hepatic $\mathrm{Pb}$ levels by 64.97 and $56.97 \%$, respectively. Similarly, the treatment with DMSA significantly decreased both $\mathrm{Pb}$ levels by 57.85 and $51.98 \%$, respectively. The combination of BVJ and DMSA (BVJ-DMSA-Pb group) synergistically $(\mathrm{CI}<1)$ reduced the $\mathrm{Pb}$ level in blood and liver (Table 2) by 84.09\% compared to $\mathrm{Pb}$ group. On the other hand, the administration of BVJ alone slightly reduced blood and hepatic $\mathrm{Pb}$ levels by 33.18 and $40.61 \%$, respectively, relative to the control group.

\section{The hepatoprotective role of BVJ, DMSA, and their combination on $\mathrm{Pb}$-induced $\mathrm{OS}$}

The graphs (II-IV) in Fig. 3 and graphs (I-III) in Fig. 4 elucidated the findings of $\mathrm{Pb}$-induced $\mathrm{OS}$ markers and changes in the body weight of rats in the studied groups. The outcomes were clustered as a heat map plot (Fig. 4IV). Administration of $\mathrm{Pb}$ induced significant $(p<$ 0.05 ) increase in the level of lipid peroxidation (Fig. $3 \mathrm{I}$ ) by $63.63 \%$ relative to control rats. Also, it induced a significant decline in the body weight (Fig. 3 III), TAC and GSH levels (Fig. 3 IV) by $86.73,39.02$, and $34.78 \%$ respectively. Moreover, the activity of SOD, GPX (Fig. 4 I), GST, and catalase (Fig. 4 II), as well as the gene 

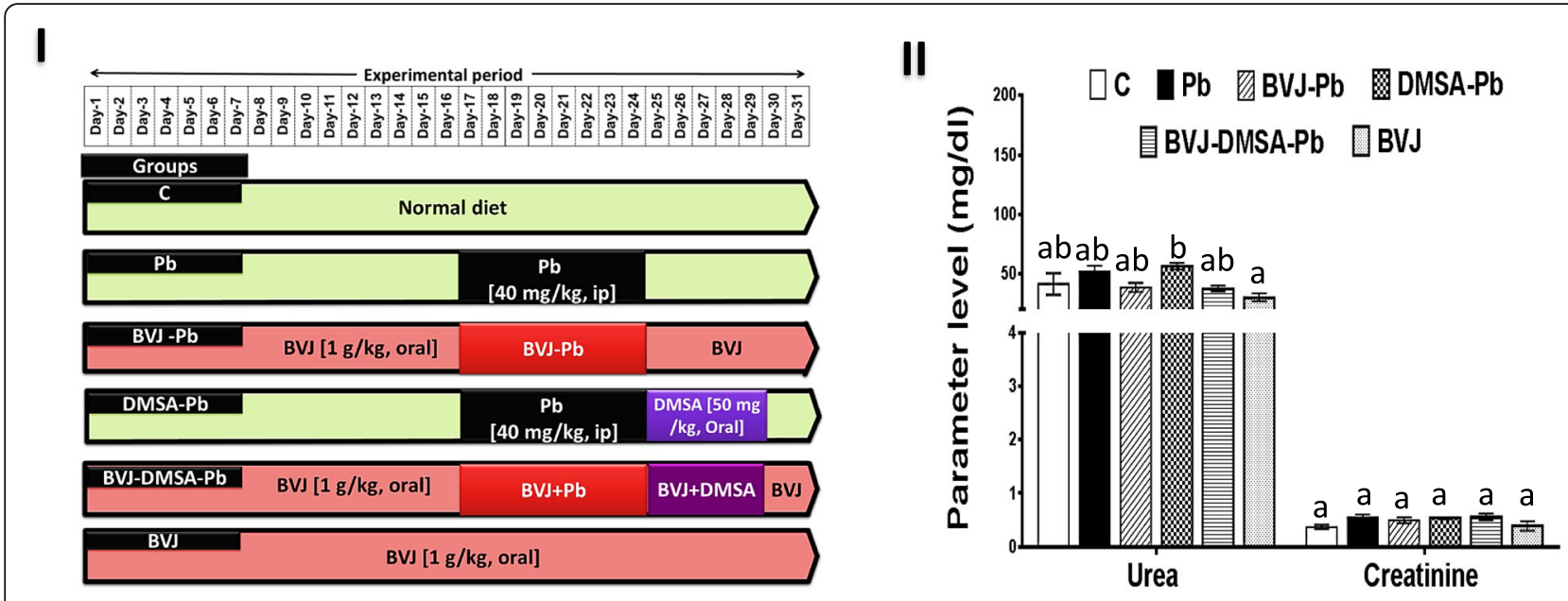

III

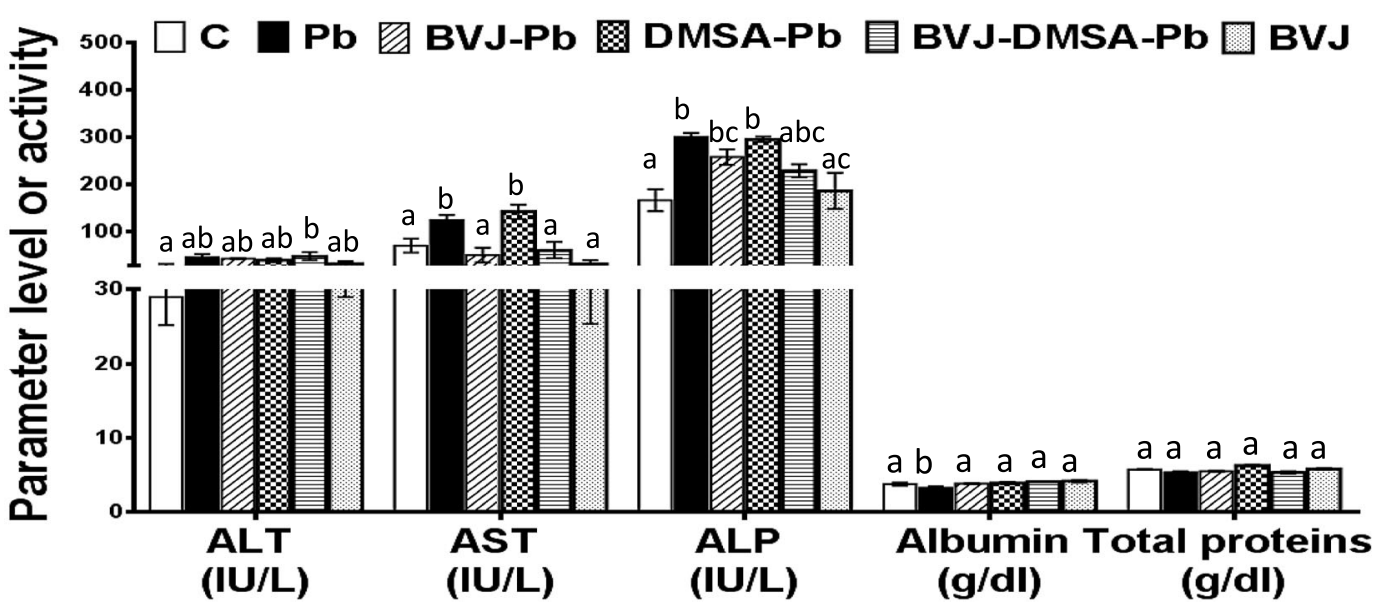

Fig. 2 The improving effects of Beta vulgarisjuice (BVJ), dimercaptosuccinic acid (DMSA), and their combination (BVJ-DMSA) on the serum kidney and liver biomarkersof Pb-intoxicated rats. (I) the experimental design (II) urea and creatinine levels (III) activities and levels of liver function parameters. Results are shown as mean \pm SE $(n=8)$. Different letters for the same parameter are significantly different at $p<0.05$. C, control; ip intraperitoneal; $\boldsymbol{A} \boldsymbol{L T}$, alanine aminotransferase; $\boldsymbol{A S T}$, aspartate aminotransferase; $\boldsymbol{A L P}$, alkaline phosphatase

expression of GST $\alpha 1$ (Fig. 4 IV), were depleted significantly $(p<0.05)$ after $\mathrm{Pb}$ administration by $53.81,27.02$, $37.61,26.96$, and $33.70 \%$, respectively.

The intake of BVJ, before, during, and after $\mathrm{Pb}$ administration significantly $(p<0.05)$ prevented the elevation in the lipid peroxidation level and the decrease in the experimental animal's body weight by 11.11 and $522.02 \%$, respectively, compared to $\mathrm{Pb}$ group. In addition, the administration of BVJ has significantly avoided the depletion in the level of TAC and GSH and the activity of SOD, GPX, and GST by $96 \%, 49.52,120.18 \%, 32.54$, and $23.53 \%$, respectively. However, it prevented the suppression of catalase activity non-significantly, and significantly $(p<0.05)$ up-regulated the gene expression of GST $\alpha 1$ by 47.32 and $160.93 \%$, respectively, compared to the $\mathrm{Pb}$ group.
Likewise, DMSA administration significantly reduced the degree of lipid peroxidation and increased the body weight of the animals tested by 11.11 and $194.79 \%$, respectively, relative to the $\mathrm{Pb}$ group. Also, DMSA intake significantly $(p<0.05)$ raised the level of both TAC (43.81\%) and GSH (43.81\%) and the activity of SOD (96.33\%) and GPX (28.94\%). However, it nonsignificantly elevated the activity of catalase (66.67\%) and the gene expression of GST $\alpha 1$ (14.63\%) and significantly reduced the activity of GST (46.09\%) compared to the $\mathrm{Pb}$ group.

The combination of BVJ and DMSA showed a synergistic $(\mathrm{CI}<1)$ effect for all the studied OS parameters, except for the GST activity and GST $\alpha 1$ expression, which showed antagonistic effects (Table 2). The administration of this combined form significantly reduced the lipid peroxidation level and elevated the animal's body 


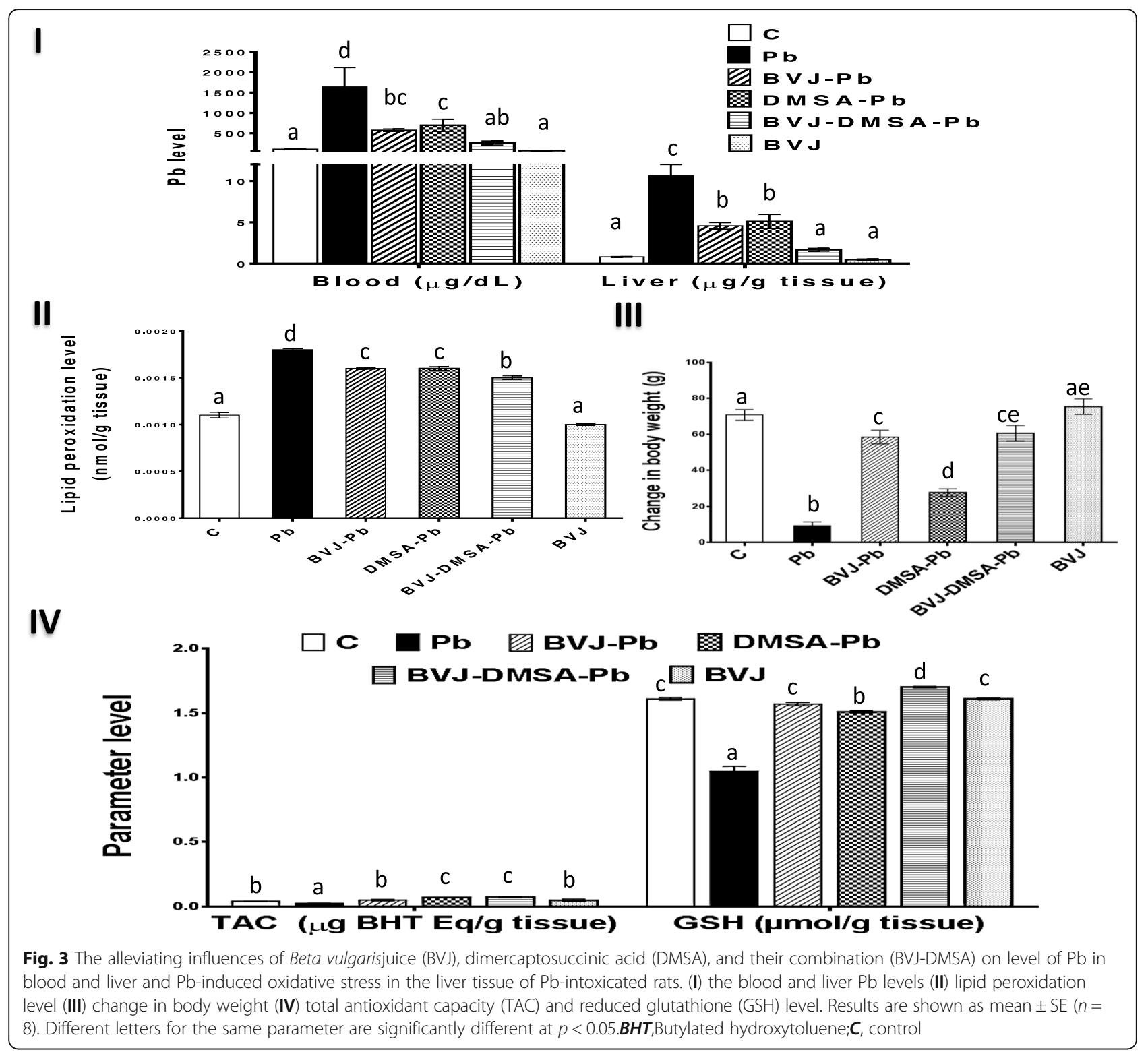

weight by 16.67 and $544.68 \%$, respectively as compared to $\mathrm{Pb}$ group. In addition, this administration significantly $(p<0.05)$ increased the level of TAC $(192 \%)$ and GSH (62.09\%),the activity of SOD (168.81\%), GPX (95.24\%), and catalase (173.81\%). However, it non-significantly affected the activity of GST (16.68\%) and the gene expression of GST $\alpha 1$ (9.35\%) relative to the $\mathrm{Pb}$ group.

Administration of BVJ alone non-significantly changed the level of lipid peroxidation (9.09\%), rat body weight $(6.45 \%)$, TAC (17.07\%), and GSH (0\%). Similarly, it non-significantly changed the activity of SOD (1.27\%), GPX (34.94\%), GST (16.20\%), and catalase $(40.21 \%)$. However, it significantly $(p<0.05)$ upregulated the gene expression of GST $\alpha 1$ by $104.30 \%$ relative to the control group.
The hepatoprotective role of BVJ, DMSA, and their combination on $\mathrm{Pb}$-induced inflammation and DNA fragmentation

Fig. 5(I-III) revealed the effect of BVJ, DMSA, and their combination on the inflammatory markers (IL-6 and NO) and DNA fragmentation. These parameters and others that were elevated by $\mathrm{Pb}$ were hierarchically clustered by the heat map diagram (Fig. 5IV). The results showed that the administration of $\mathrm{Pb}$ caused a significant elevation in the level of IL-6 (143.74\%) and DNA fragmentation in hepatocytes (34.61\%), but nonsignificantly affect the NO level (27.16\%).

Administration of BVJ, before, during, and after $\mathrm{Pb}$ administration extremely depleted the IL-6 level (35.29\%) and DNA fragmentation (30.88\%). In contrast, it 


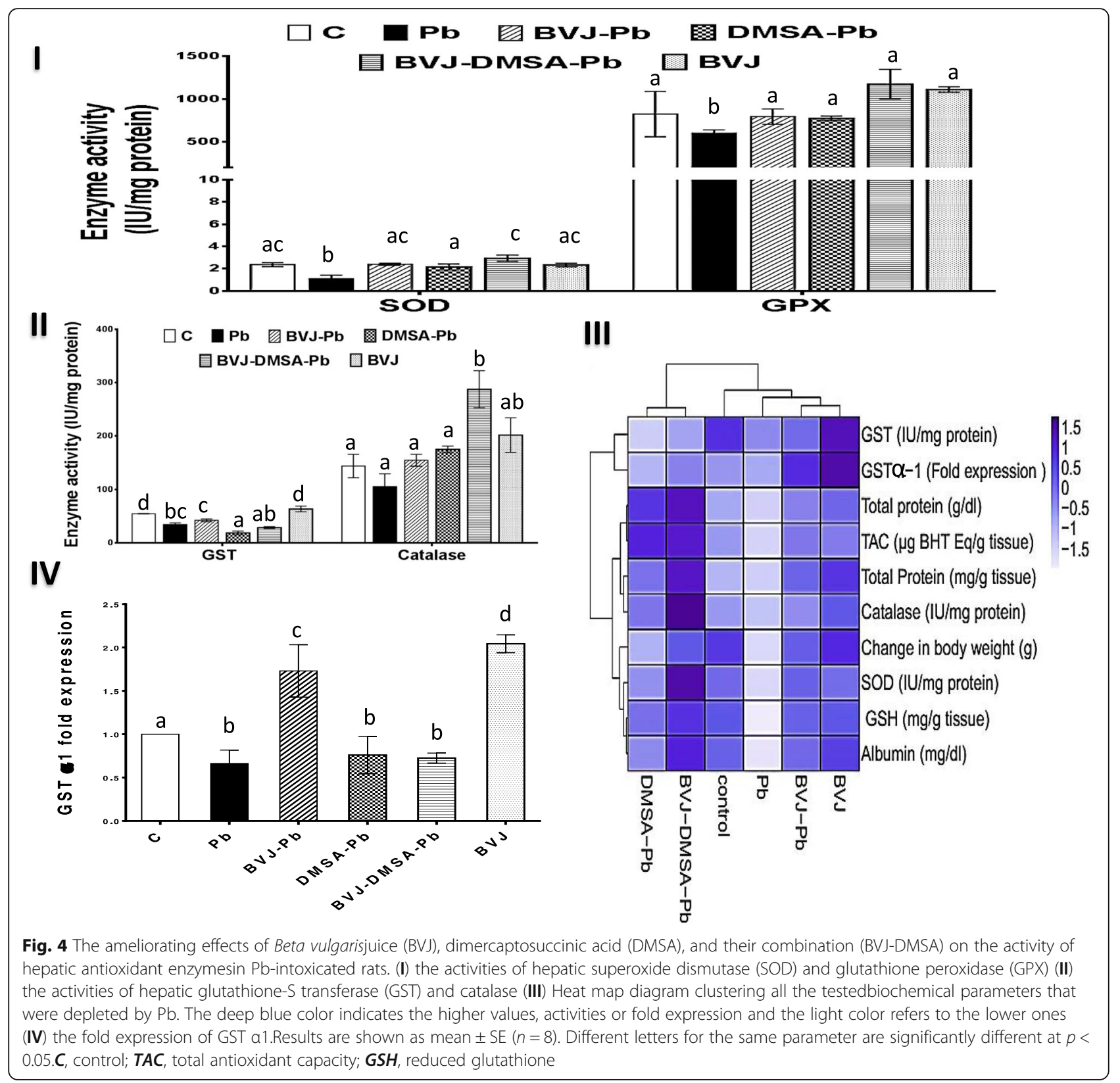

significantly $(p<0.05)$ elevated the NO level by 63.11\%relative to $\mathrm{Pb}$ group. While DMSA treatment non-significantly depleted any of these parameters by about $9 \%$. On the other hand, the combination between BVJ and DMSA revealed a synergistic $(\mathrm{CI}<1)$ anti-inflammatory effect and a synergistic suppressing effect on DNA fragmentation (Table 2). This combination significantly $(p<0.05)$ reduced the hepatic level of IL-6 and DNA fragmentation by $27.90 \%$ and slightly (1.21\%) changed the NO level in liver tissue. However, the administration of BVJ alone for 31 days altered the hepatic level of IL-6 and DNA fragmentation non-significantly by 13.61 and $12.09 \%$, respectively, and substantially $(59.67 \%)$ raised the NO level relative to control rats.

Histopathological changes of the liver in the $\mathrm{Pb}$ intoxicated rats before and after administration of BVJ, DMSA, or their combination

The control liver tissues displayed typical morphological appearance with normal polygonal (pentagonal and hexagonal) hepatocytes that are separated by asymmetrical sinusoids containing Kupffer cells (Fig. 6). This normal architecture was disrupted after $\mathrm{Pb}$ administration. Hence, the normal cordlike arrangement of the hepatocytes was damaged and cells revealed vacuolated 


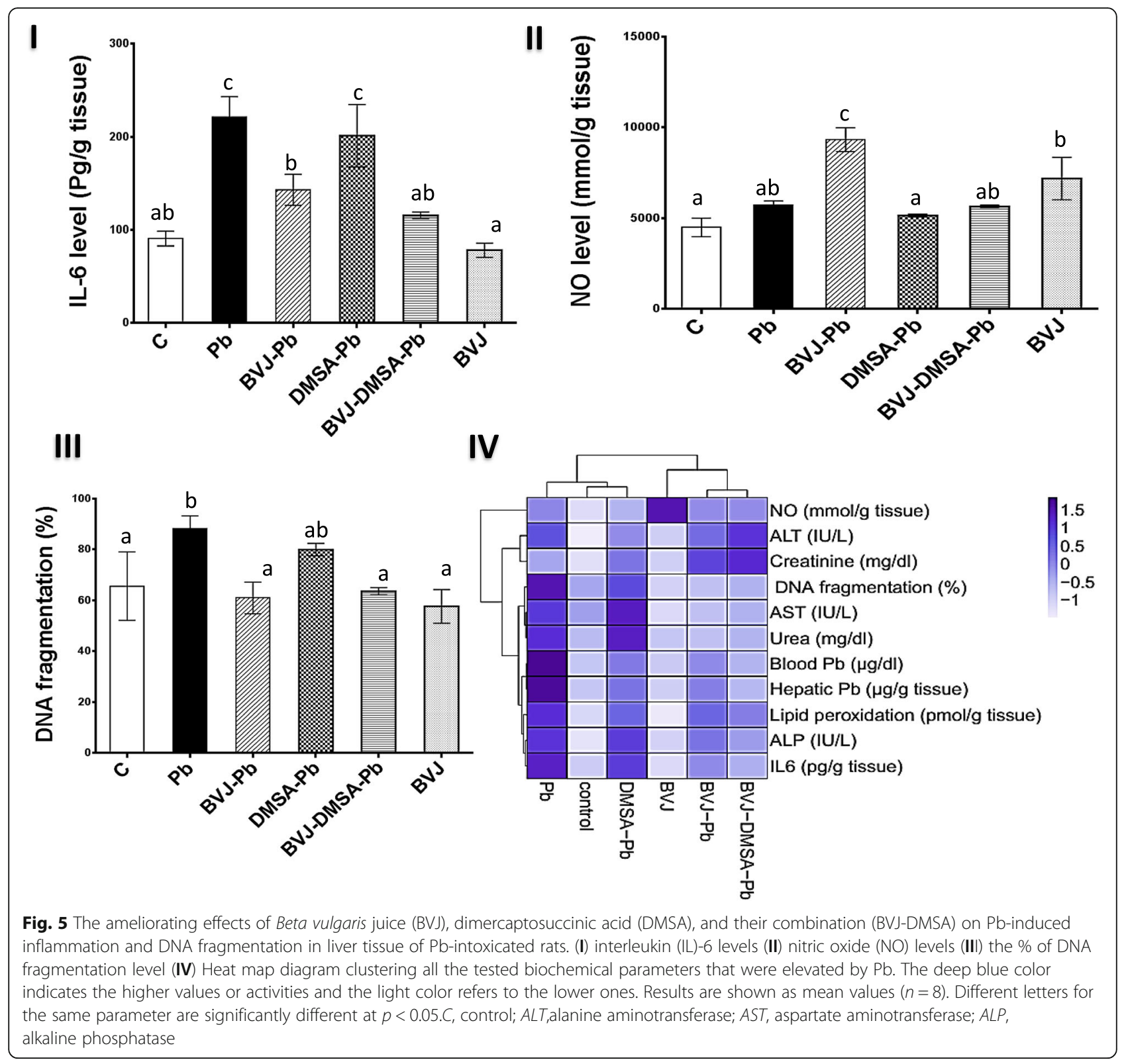

cytoplasm, pyknotic nuclei, and single-cell necrosis. In addition, there was an infiltration of inflammatory cells and congestion of the portal vein and sinusoids. The administration of BVJ, before, during, and after $\mathrm{Pb}$, protected from these damage effects caused by $\mathrm{Pb}$ and there was only congestion of the central vein with normal hepatocytes and sinusoids. However, the treatment with DMSA demonstrated feathery degenerative hepatocytes with congested central vein and sinusoids. The combination of BVJ and DMSAshowed normal hepatic tissue architecture with only focal lytic inflammation. On the other hand, the administration of BVJ alone for 31 days had no adverse effect on the hepatic architecture.

\section{Discussion}

The fruits, vegetables, and herbs are rich in bioactive compounds with various health benefits such as antioxidative, atherosclerosis, anticarcinogenic, and antimutagenic inhibitory potentials $[11,39,40]$. The current study revealed the presence of multiple bioactive constituents in BVJ, including phenolics (flavonoids, anthocyanins, and tannins), betalains, and vitamin $C$ (Table 1 ). These compounds have redox power and can scavenge and neutralize free radicals. Therefore, BVJ has ferric reducing power, scavenge $\mathrm{ABTS}^{+}$, and prevent $\beta$-carotene bleaching (Fig. 1). These results were following the previous studies that confirm the antioxidant activities of BV [41]. Moreover, DMSA revealed antioxidant potency 


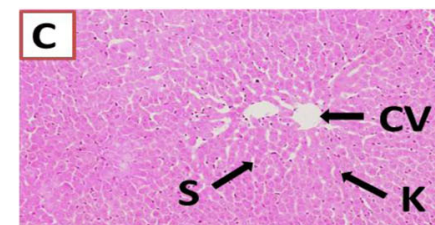

$10 x$
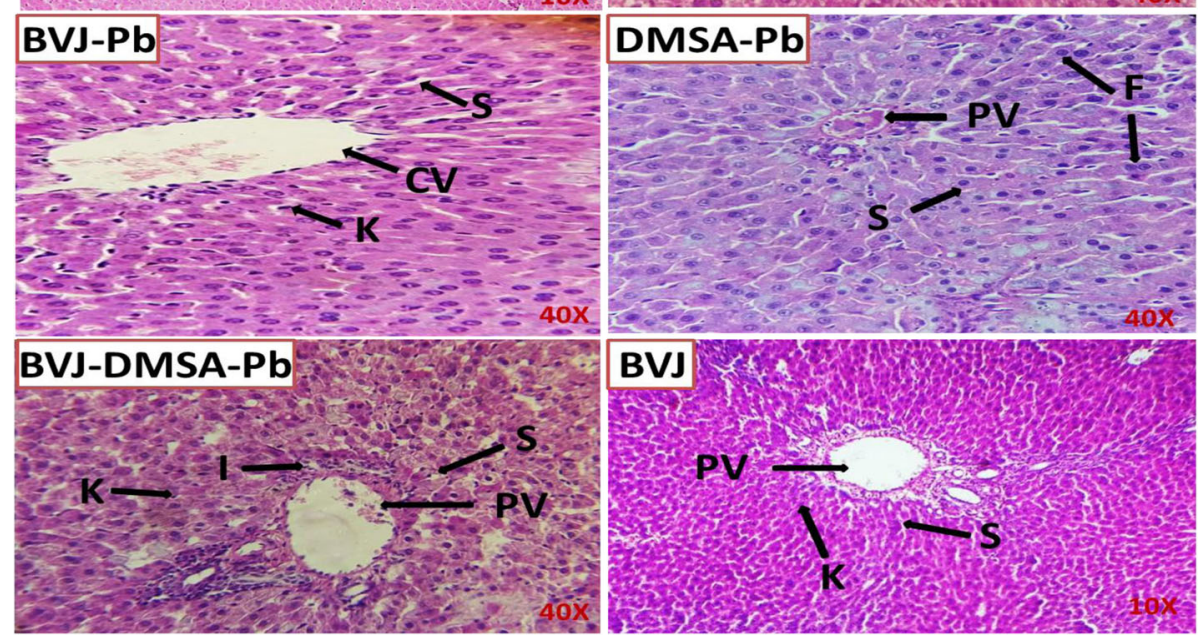

Fig. 6 Histopathological changes in the liver of rats in all the studied groups. BVJ, Beta vulgaris juice; $C$, control;CV,central vein; $D M S A$, dimercaptosuccinic acid; F, feathery degeneration of hepatocytes; I,focal lytic inflammation; $K$, kupffer cells; $N$, single cells necrosis; $P$, pyknotic nuclei; $P V$, portal vein; $S$, sinusoids; $V$, vaculation; 10x, 40x, magnification of the image

against the studied free radicals (Fig. 1) that probably owed to its structure that contains dithiol compound (-SH groups) [42]. DMSA revealed higher potency towards ABTS radical while BVJ showed higher $\beta$ carotene-linoleate bleaching ability and both had the same ferric reducing power. The combination of DMSA and BVJ had synergistic efficacy $(\mathrm{CI}<1)$ relative to those individuals, except for the $\beta$-carotene-linoleate bleaching study (Table 2). This will enhance the quality and therapeutic potential of this combination.

The present study demonstrated the hepatoprotective role of BVJ, DMSA, and their combination on the $\mathrm{Pb}$ induced hepatotoxicity in rats. The liver is known to be the largest storehouse of $\mathrm{Pb}$ [1] as well as, one of the main organs concerned with storing, biotransformation, and removal of $\mathrm{Pb}$. This may result in an elevation in the activity of AST and ALP and a decrease in serum albumin levels, which may be indicative of hepatic damage [43]. Pb caused OS in the liver by upregulating lipid peroxidation causing loss of membrane integrity and elevation of the ROS. This will influence the redox state of the cell and antioxidant indices. GSH is one of the cellular antioxidants used to detoxify peroxides and various electrophilic compounds using GST and GPX. In addition, GSH neutralized the radicals-generated from $\mathrm{Pb}$ metabolism and make chelation and detoxification of it [3]. By accumulating $\mathrm{Pb}$ and increasing the $\mathrm{Pb}$ level over time, this will cause exhaustion of the antioxidant enzymes including SOD, catalase, and GPX. In addition, these enzymes have been inactivated by $\mathrm{Pb}$ due to inhibition of their functional $-\mathrm{SH}$ groups. Also, $\mathrm{Pb}$ can chelate selenium, which is an important cofactor for GPX activity [3]. The GST activity decreased after $\mathrm{Pb}$ administration that may be owed to increase the production of peroxides after $\mathrm{Pb}$ metabolism that leads to exhaustion of the enzyme. Also, the gene expression of GST $\alpha 1$ was downregulated after $\mathrm{Pb}$ intake. This may be related to the ROS production that caused oxidative damage for the DNA in the liver [44]. All of these damage effects induced by $\mathrm{Pb}$ caused depletion of the TAC in liver tissue. Moreover, $\mathrm{Pb}$ administration caused hepatic inflammation by raising the level of early mediators (IL-6) and secondary mediators (ROS). IL-6 is a pro-inflammatory cytokine that induces neutrophil influx, prostaglandin synthesis, and $\mathrm{T}$ and $\mathrm{B}$ lymphocytes activation [45]. In addition, ROS production was considered to be an essential factor in inducing inflammation due to the crosstalk between ROS and NF-KB, one of the most essential inflammatory pathways. Induction of OS and inflammation in the cell upon $\mathrm{Pb}$ intake is toxic and can trigger both apoptotic and necrotic cell death [46]. Therefore, the DNA fragmentation level was massively elevated following $\mathrm{Pb}$ injection (Fig. 5 III). All of these damage effects are clearly observed in the morphology of the liver tissue of the $\mathrm{Pb}$ intoxicated rats (Fig. 6). 
The present research found that BVJ administration before, during and after $\mathrm{Pb}$ intoxication significantly lowered blood and hepatic $\mathrm{Pb}$ levels and clearly enhanced the blood profile of these rats. Moreover, this extract capable of returning the homeostasis and the balance between the hepatic free radicals content and the antioxidant status to ameliorate the $\mathrm{Pb}$ induced oxidative stress. This can be indicated by lowering the lipid peroxidation level and increasing the antioxidant indices, including TAC, GSH, SOD, GPX, and GST $\alpha 1$. These parameters have not only been enhanced, but most of them have also been normalized (Figs. 3, 4). However, the BVI did not have any impact on the activity of both hepatic catalase and GST and significantly increased the gene expression of GST $\alpha 1$. The improvement in body weight change in the rats of this group reflects this enhanced impact. The ability of BV extracts to alleviate the OS induced by different toxicants was studied before [39]. The potent antioxidant role of BVJ may be related to its ingredients, including flavonoids, phenolic acids, and betalains (Table 3). Hence, gallic, vanillic, syringic, ellagic, rosmarinic, benzoic, and o-coumaric acids proved their potency as antioxidants. Also, flavonoids [47], as well as betalains [41], can improve the OS state and return the cellular homeostasis. However, the upregulation of GST $\alpha 1$ expression may be linked to the existence of betalains that can induce the hepatic phase II enzymes, like GST $\alpha 1$, as studied before [48]. Additionally, administration of BVJ prevented the elevation of the inflammatory mediators like IL-6, but upregulated the NO level in the liver tissues (Fig. 5). The antiinflammatory activity of BVJ constituents [47] may be the cause of its depleting effect on IL-6 level (Table 3). While the elevation of NO level may be owed to its nitrate content as reported before [49]. The elevation of $\mathrm{NO}$ with the depletion of IL-6 and OS can confirm the absence of the pathological action of NO. Hence, the previous studies suggested that the elevation of $\mathrm{NO}$ after BV administration is associated with increasing the production of muscle power through an unclear mechanism [49]. Therefore, BVJ administration, before, during, and after $\mathrm{Pb}$ can protect from both the oxidative and inflammatory stress in the hepatic tissue. This may be the cause for the normalization of the DNA fragmentation level in the hepatic tissue of rats administered this extract. Hence, several studies proved the implication of OS and inflammation in cell death [50]. The present study found also that all of the studied biochemical parameters were in harmony with the histopathological outcomes (Fig. 6).

Additionally, the current study proved the safety of BVJ intake for 31 days. Hence, there were no pathological changes in the studied OS and inflammatory indices in hepatic tissues as well as the studied blood profile. Only a substantial increase in NO level and significant elevation of GST $\alpha 1$ gene expression were observed in the rats of this group. This may be owed to its nitrate richness and its betalains content, respectively as discussed earlier. The hepatic histology of BVI-treated rats alone disclosed ordinary architecture which confirmed the safety of this extract. These findings will increase the protective efficiency and the importance of BVJ.

On the other hand, this study reported the therapeutic effect of DMSA on Pb-induced hepatic damage. The effectiveness of DMSA appears almost as BVI potency in most of the studied markers. It was able to ameliorate the $\mathrm{Pb}$-induced $\mathrm{OS}$ and inflammation. This may be related to its structure containing the reduced sulfhydryl groups that enable it to act as a potent antioxidant molecule and improved the hepatic OS and in turn the inflammatory response and DNA fragmentation [42]. Although the level of IL- 6 did not show any improvement, which implies the presence of the hepatic inflammation. This has been seen in the histology of the liver tissue of these rats, in addition to feathery hepatocytes, which may be owed to the few side effect of DMSA as studied before [8]. Such findings were consistent with the previous research by Ercal et al. [51].

Table 3 Summary of the hepatoprotective effect of Beta vulgaris juice (BVJ) phytochemicals against Pb toxicity

\begin{tabular}{ll}
\hline Phytochemical compound & The hepatoprotective mechanism \\
\hline Betalains & - antioxidant and free radicals scavenging. up-regulation of GST a1 expression \\
Rutin & - scavenge and neutralize free radicals. \\
Flavonoids & - scavenge and neutralize free radicals. Significant prevention of IL-6 production. \\
Gallic acid & Improvement of antioxidant indices and decrease lipid peroxidation level. \\
Syringic acid & [47] \\
Vanillic acid & \\
Ellagic acid \\
Rosmarinic acid \\
Benzoic acid \\
O- Coumaric acid
\end{tabular}


The present study also studied the anti-toxicity effect of the combination between both BVJ and DMSA (BVJDMSA-Pb). This combination revealed a synergistic antioxidant and anti-inflammatory effects in most of the studied parameters as indicated by the CI value (Table 2). Several combination studies of DMSA and other antioxidants were previously investigated and gave remarkable results against $\mathrm{Pb}$-induced hepatotoxicity, such as the results of Flora et al. [52]. Here, in addition to the synergistic efficiency of this combination, it also reduced the observed side effect of DMSA on the hepatic tissue. Hence, the histopathological results of this combination showed no pathological changes in the hepatic structure (Fig. 6). The obtained synergism between DMSA and BVJ may be related to their antioxidant properties. As several studies have shown synergistic antioxidant and anti-inflammatory impacts after the combination of different antioxidant extracts or drug and extract $[18,34,53]$. However, the exact mechanism for this synergism needs further investigations and analyses.

\section{Conclusion}

In summary, our results clearly revealed that BVJ has potent efficiency in the protection from $\mathrm{Pb}$-induced hepatotoxicity via reducing the accumulation of $\mathrm{Pb}$ in blood and liver and by preventing $\mathrm{Pb}$-induced oxidative and inflammatory stress. Likewise, the administration of DMSA (the known $\mathrm{Pb}$ chelator) showed enhancing effects from $\mathrm{Pb}$ toxicity, but produced certain adverse impacts on the liver. However, the intake of BVJ and DMSA mixture after $\mathrm{Pb}$ injection showed synergistic antioxidant and anti-inflammatory influences with minimal side effects on the hepatic tissue. Therefore, BVJ is a successful extract in protection from $\mathrm{Pb}$-induced hepatotoxicity and its combination with DMSA exerted a potent therapeutic effect against this toxicity.

\section{Abbreviations \\ ABTS 2,2: Azino-bis(3-ethylbenzthiazoline-6-sulfonic acid; ALP: Alkaline phosphatase; BV: Beta vulgaris; BHT: Butylated hydroxytoluene; BVJ: BV juice juice; Cl: Combination index; Cy-3-glc: Cyanidin-3-glucoside; DMSA: Meso-2,3- dimercaptosuccinic acid; DR: Degradation rate; GSH: Glutathione; GST: Glutathione-s transferase; GPX: Glutathione peroxidase; 4-HCA: 4- hydroxycinnamic acid; IL-6: Interleukin-6; NO: Nitric oxide; OS: Oxidative stress; RNS: Reactive nitrogen species; ROS: Reactive oxygen species; SOD: Superoxide dismutase; TBA: Thiobarbituric acid; TBARS: Thiobarbituric acid reactive substances; TAC: Total antioxidant capacity}

\section{Acknowledgments}

Not Applicable.

\section{Authors' contributions}

Conception and design: NZS; conducted experiments: SAA; analysis and interpretation of the data: SAA and $\mathrm{NHH}$; writing, revision, and final editing: NZS, SAA, FAKM, MALE, IMT and NHH. All authors have read and approved the manuscript.

\section{Funding}

This research received no specific grant from funding agencies in the public, commercial, or not-for-profit sectors.

\section{Availability of data and materials}

The data that supported this article are available in Tables 1, 2 and, Figs. 1, 2, $3,4,5,6$. The data sets analyzed during the present study are available from the corresponding author on a reasonable request.

\section{Ethics approval and consent to participate}

The current study followed, the Research Ethical Committee (REC) published by the National Health and Medical Research Council policies and the Ministry of Health and Population, Egypt. This work has been received permission from the Department of Medical Biotechnology (SRTA-City) and the Department of Biochemistry (Faculty of Science, Alexandria University).

\section{Consent for publication}

Not applicable.

\section{Competing interests}

Authors have no conflicts of interest to declare.

\section{Author details}

${ }^{1}$ Biochemistry Department, Faculty of Science, Alexandria University, Alexandria 21511, Egypt. ${ }^{2}$ Department of Nucleic Acid Research, Genetic Engineering and Biotechnology Research Institute, City of Scientific Research and Technological Applications (SRTA-City), New Borg EL-Arab, Alexandria 21934, Egypt. ${ }^{3}$ Department of Pathology, Faculty of Medicine, University of Alexandria, Alexandria, Egypt.

Received: 20 March 2020 Accepted: 19 August 2020

Published online: 01 September 2020

\section{References}

1. Trefts E, Gannon M, Wasserman DH. The liver. Curr Biol. 2017;27(21):R1147-51.

2. Robin S, Sunil K, Nidhi S. Different models of hepatotoxicity and related liver diseases: a review. Int Res J Pharm. 2012;3(7):86-95.

3. Fan Y, Zhao X, Yu J, Xie J, Li C, Liu D, et al. Lead-induced oxidative damage in rats/mice: a meta-analysis. J Trace Elem Med Biol. 2020;58:126443.

4. Shalaby A. Antioxidant compounds, assays of determination and mode of action. African J Pharm Pharmacol. 2013;7(10):528-39.

5. Dadpour B, Afshari R, Mousavi SR, Kianoush S, Keramati MR. Clinical and laboratory findings of Lead hepatotoxicity in the Workers of a Car Battery Manufacturing Factory. IRAN J Toxicol. 2016;10(2):1-6.

6. Flora SJS, Pachauri V. Chelation in metal intoxication. Int J Environ Res Public Health. 2010;7(7):2745-88

7. El-Khishin IA, El-fakharany YMM, Abdel Hamid OI. Role of garlic extract and silymarin compared to dimercaptosuccinic acid (DMSA) in treatment of lead induced nephropathy in adult male albino rats. Toxicol Rep. 2015;8(2):824-32.

8. Blaurock-Busch E. Comparison of chelating agents DMPS, DMSA and EDTA for the diagnosis and treatment of chronic metal exposure. Br J Med Med Res. 2014:4(9):1821-35.

9. Flora SJS, Saxena G, Gautam P, Kaur P, Gill KD. Response of lead-induced oxidative stress and alterations in biogenic amines in different rat brain regions to combined administration of DMSA and MiADMSA. Chem Biol Interact. 2007;170(3):209-20.

10. Alqasoumi S. Carbon tetrachloride-induced hepatotoxicity: protective effect of "rocket" Eruca sativa L. in rats. Am J Chin Med. 2010;38(1):75-88.

11. Mirmiran P, Houshialsadat Z, Gaeini Z, Bahadoran Z, Azizi F. Functional properties of beetroot (Beta vulgaris) in management of cardio-metabolic diseases. Nutr Metab. 2020;38(1):1-15.

12. Taga MS, Miller EE, Pratt DE. Chia seeds as a source of natural lipid antioxidants. J Am Oil Chem Soc. 1984;61(5):928-31.

13. Zhishen J, Mengcheng $T$, Jianming $W$. The determination of flavonoid contents in mulberry and their scavenging effects on superoxide radicals. Food Chem. 1999;64(4):555-9.

14. Price ML, Van Scoyoc S, Butler LG. A critical evaluation of the vanillin reaction as an assay for tannin in sorghum grain. J Agric Food Chem. 1978; 26(5):1214-8.

15. Stintzing FC, Schieber A, Carle R. Evaluation of colour properties and chemical quality parameters of cactus juices. Eur Food Res Technol. 2003; 216:396-407.

16. Wrolstad RE, Acree TE, Decker EA, Penner MH, Reid DS, Schwartz SJ, et al. Handbook of Food Analytical Chemistry. Hoboken, NJ, USA: Wiley; 2005. p. 5-33. 
17. Omaye ST, David Turnbull J, Sauberlich HE. Selected methods for the determination of ascorbic acid in animal cells, tissues, and fluids. Methods Enzymol. 1979;62:3-11.

18. Abu-Serie MM, Habashy NH. The ameliorating effect of the combined extract from Greek Thymus vulgaris and bee's honey on the hydrocortisone-induced osteoporosis in rat bone cells via modulating the bone turnover, oxidative stress, and inflammation. RSCAdv. 2018;8(50): 28341-55.

19. Tyagi S, Singh A, Saxena A, Patel B. In vitro antioxidant activity of Methanolic and aqueous extract of Flacourtia indica Merr. Am J Sci Res. 2010;5(3):201-6

20. Re R, Pellegrini N, Proteggente A, Pannala A, Yang M, Rice-Evans C. Antioxidant activity applying an improved ABTS radical cation decolorization assay. Free Radic Biol Med. 1999;26(9-10):1231-7.

21. Barreira JCM, Ferreira ICFR, Oliveira MBPP, Pereira JA. Antioxidant activities of the extracts from chestnut flower, leaf, skins and fruit. Food Chem. 2008; 107(3):1106-13.

22. Oyaizu M. Studies on products of browning reaction antioxidative activities of products of browning reaction prepared from glucosamine. Japanese J Nutr Diet. 1986;44(6):307-15.

23. Abd El-Ghffar EA, El-Aal AA. Ameliorating effect of L-cysteine on lead acetate-induced hepatotoxicity and nephrotoxicity in male mice. Prog Nutr. 2018;20(2):79-89.

24. Uluozlu OD, Tuzen M, Mendil D, Soylak M. Assessment of trace element contents of chicken products from Turkey. J Hazard Mater. 2009;163(2-3): 982-7.

25. Ohkawa H, Ohishi N, Yagi K. Assay for lipid peroxides in animal tissues by thiobarbituric acid reaction. Anal Biochem. 1979;95(2):351-8.

26. Ellman GL. Tissue sulfhydryl groups. Arch Biochem Biophys. 1959;82(1):70-7.

27. Marklund S, Marklund G. Involvement of the superoxide anion radical in the autoxidation of pyrogallol and a convenient assay for superoxide dismutase. Eur J Biochem. 1974;47(3):469-74

28. Paglia DE, Valentine WN. Studies on the quantitative and qualitative characterization of erythrocyte glutathione peroxidase. J Lab Clin Med. 1967; 70(1):158-69.

29. Hadwan MH. Simple spectrophotometric assay for measuring catalase activity in biological tissues. BMC Biochem. 2018;19(1):7.

30. Habig WH, Pabst MJ, Jakoby WB. Glutathione S transferases. The first enzymatic step in mercapturic acid formation. J Biol Chem. 1974;249(22): 7130-9.

31. Ohnishi ST, Barr JK. A simplified method of quantitating protein using the biuret and phenol reagents. Anal Biochem. 1978;86(1):193-200.

32. Marcocci L, Maguire JJ, Droy-Lefaix MT, Packer L. The nitric oxidescavenging properties of Ginkgo biloba extract EGb 761. Biochem Biophys Res Commun. 1994:201(2):748-55

33. Wyllie AH. Glucocorticoid-induced thymocyte apoptosis is associated with endogenous endonuclease activation. Nature. 1980:284(5756):555-6.

34. Habashy NH, Abu Serie MM, Attia WE, Abdelgaleil SAM. Chemical characterization, antioxidant and anti-inflammatory properties of Greek Thymus vulgaris extracts and their possible synergism with Egyptian Chlorella vulgaris. J Funct Foods. 2018;40:317-28.

35. Chou TC. Theoretical basis, experimental design, and computerized simulation of synergism and antagonism in drug combination studies. Pharmacol Rev. 2006;58(3):621-81.

36. Zhou JR, Blackburn GL, Walker WA. Symposium introduction: metabolic syndrome and the onset of cancer. Am J Clin Nutr. 2007;86(3):S817-9.

37. Slaoui M, Fiette L. Histopathology procedures: from tissue sampling to histopathological evaluation. Methods Mol Biol. 2011;691:69-82.

38. Metsalu T, Vilo J. ClustVis: a web tool for visualizing clustering of multivariate data using principal component analysis and heatmap. Nucleic Acids Res. 2015:43:W566-70.

39. Clifford T, Howatson G, West DJ, Stevenson EJ. The potential benefits of red beetroot supplementation in health and disease. Nutrients. 2015;7(4):2801-22.

40. El Gamal AA, Alsaid MS, Raish M, Al-Sohaibani M, Al-Massarani SM, Ahmad $A$, et al. Beetroot (Beta vulgaris L.) extract ameliorates gentamicin-induced nephrotoxicity associated oxidative stress, inflammation, and apoptosis in rodent model. Mediat Inflamm. 2014;2014:1-12.

41. Georgiev VG, Weber J, Kneschke EM, Denev PN, Bley T, Pavlov Al. Antioxidant activity and phenolic content of betalain extracts from intact plants and hairy root cultures of the red beetroot Beta vulgaris cv. Detroit dark red. Plant Foods Hum Nutr. 2010;65(2):105-11.
42. Bjørklund G, Crisponi G, Nurchi VM, Cappai R, Djordjevic AB, Aaseth J. A review on coordination properties of thiol-containing chelating agents towards mercury, cadmium, and lead. Molecules. 2019;24(18):E3247.

43. Omobowale TO, Oyagbemi AA, Akinrinde AS, Saba AB, Daramola OT, Ogunpolu BS, et al. Failure of recovery from lead induced hepatoxicity and disruption of erythrocyte antioxidant defence system in Wistar rats. Environ Toxicol Pharmacol. 2014;37(3):1202-11.

44. Liu CM, Ma JQ, Sun YZ. Puerarin protects the rat liver against oxidative stress-mediated DNA damage and apoptosis induced by lead. Exp Toxicol Pathol. 2012;64(6):575-82.

45. Metryka E, Chibowska K, Gutowska I, Falkowska A, Kupnicka P, Barczak K, et al. Lead (Pb) exposure enhances expression of factors associated with inflammation. Int J Mol Sci. 2018;19(6):1813.

46. Morgan MJ, Liu ZG. Crosstalk of reactive oxygen species and NF-KB signaling. Cell Res. 2011:21(1):103-15.

47. Szwajgier D, Borowiec K, Pustelniak K. The neuroprotective effects of phenolic acids: molecular mechanism of action. Nutrients. 2017;9(5):E477.

48. Kujala T, Loponen J, Pihlaja K. Betalains and Phenolics in red beetroot (Beta vulgaris) Peel extracts: extraction and characterisation. J Biosci. 2001;56(5-6): 343-8.

49. Domínguez R, Maté-Muñoz JL, Cuenca E, García-Fernández P, Mata-Ordoñez F, Lozano-Estevan MC, et al. Effects of beetroot juice supplementation on intermittent high-intensity exercise efforts. J Int Soc Sports Nutr. 2018;15:2-12.

50. Khanna P, Ong C, Bay BH, Baeg GH. Nanotoxicity: an interplay of oxidative stress, inflammation and cell death. Nanomaterials. 2015;5(3):1163-80.

51. Ercal N, Treeratphan P, Hammond TC, Matthews RH, Grannemann NH, Spitz DR. In vivo indices of oxidative stress in lead-exposed C57BL/6 mice are reduced by treatment with meso-2,3-dimercaptosuccinic acid or $\mathrm{N}$ acetylcysteine. Free Radic Biol Med. 1996;21(2):157-61.

52. Flora SJS, Pande M, Bhadauria S, Kannan GM. Combined administration of taurine and meso 2,3-dimercaptosuccinic acid in the treatment of chronic lead intoxication in rats. Hum Exp Toxicol. 2004;23(4):157-66.

53. Abu-Serie MM, Habashy NH. Vitis vinifera polyphenols from seedless black fruit act synergistically to suppress hepatotoxicity by targeting necroptosis and pro-fibrotic mediators. Sci Rep. 2020;10:2452-66.

\section{Publisher's Note}

Springer Nature remains neutral with regard to jurisdictional claims in published maps and institutional affiliations.
Ready to submit your research? Choose BMC and benefit from:

- fast, convenient online submission

- thorough peer review by experienced researchers in your field

- rapid publication on acceptance

- support for research data, including large and complex data types

- gold Open Access which fosters wider collaboration and increased citations

- maximum visibility for your research: over $100 \mathrm{M}$ website views per year

At $\mathrm{BMC}$, research is always in progress.

Learn more biomedcentral.com/submission 